\title{
The economic impact of morbid obesity
}

\author{
Eldo E. Frezza $\cdot$ Mitchell S. Wachtel
}

Published online: 30 January 2009

(C) Springer Science+Business Media, LLC 2009

The percentage of Americans who are obese doubled from $15 \%$ in 1968 to $30 \%$ currently. An obesity epidemic is obvious and expected to worsen [1-5]. Lower productivity and higher health care costs resulting from obesity and its comorbidities have led to proposals for governmental intervention [6-10]. Methods for quantifying the costs of obesity costs and the benefits of treatment remain controversial [11-13]. Nonetheless, it is well established that about $10 \%$ of health care dollars are devoted to obesity treatment, which is economically justified by the increased absenteeism and decreased productivity associated with this disorder [14-19].

Bariatric surgery gives to the patient increased qualityadjusted life years [20]. A recent review of 18 trials involving 1,891 subjects concluded that surgical management of obesity yielded an average of 30 to $28 \mathrm{~kg}$ more weight loss than medical management after 2 years, with marked amelioration of obesity-related diseases such as diabetes, hypertension, and hypertriglyceridemia [21]. Metabolic syndrome, in particular, is cured by surgery in $95.6 \%$ of cases [22]. Ultimately, surgical management yields, at 5 years, a mortality rate $42 \%$ that of medical management and an $89 \%$ reduction in the relative risk of death [23].

That bariatric surgery benefits the health of patients is unquestioned. This review, however, focuses on the benefits of this surgery with respect to the general economy as

\section{E. E. Frezza $(\bowtie)$}

University of Alabama, 2523 Park Lane Cr. suite E,

Birmingham, AL, USA

e-mail: eefrezza@msn.com

M. S. Wachtel

Department of Pathology, Texas Tech University Health

Sciences Center, Lubbock, TX, USA well as workers and insurers, exemplifying matters by analyzing the costs of diabetes, one of obesity's comorbidities.

\section{Benefits of surgery to the economy as a whole}

A recent study focused on obesity's economic impact on New Mexico's state-wide economy [24]. It was determined that the total labor income impact is nearly \$200 million, representing $\$ 1,660$ of output income per household and $\$ 245$ of labor income per household. Obesity costs New Mexico more than 7,300 jobs and cuts state and local tax revenues by more than $\$ 48$ million. In terms of people, the annual labor income impact totals nearly \$200 million, representing $\$ 1,660$ of output income per household and $\$ 245$ of labor income per household. In terms of the state economy as a whole, the annual labor income impact totals more than $\$ 1.3$ billion.

The current value, capitalized, of output losses alone, using a 5\% net discount rate, exceeds $\$ 26$ billion. The total current value of benefits from surgery for all obese individuals is roughly $\$ 6.7$ billion. The results justify bariatric surgery costs in New Mexico if the current value of total surgical costs to the state does not exceed \$26 billion.

This analysis cannot be extrapolated to other states because of heterogeneity with respect to the impact on specialized regions, such as the Mexico-U.S. border, and on areas with differing population concentrations. Focused studies based on the particularities of the region in question are required for appropriate public health policy decisions. Moreover, when assessments of trends over time are required, time-series econometric analyses that, among other things, evaluate the data for autocorrelation usually are required [25]. 
A great value of econometric models is their ability to estimate the effect of a change in an explanatory variable on a response variable, for example, to observe how market demand responds to a change in per capita personal income. The effect of bariatric surgery on the general economy requires further study. Although many studies suggest that bariatric surgical benefits outweigh their costs [13], others have not arrived at the same conclusion [4]. No matter what the conclusions of such analyses are, effective cost-reduction strategies will play a vital role in convincing payers concerning the value of bariatric procedures.

\section{Benefits of surgery to workers and insurers}

Some, but not all, studies show that obesity lowers wages $[26,27]$. In terms of productivity, recent papers have shown that the cost of obesity among full-time employees is highly concentrated among those eligible for bariatric surgery, which is only one-third of the obese population; that there is increased work loss by the patients who are surgically ineligible; and that in less than 4 years, bariatric surgery yields a net economic gain. Benefits are greater among younger workers and higher-earning individuals [28-30]. Given that bariatric surgery has been shown to increase life expectancy, productivity benefits are likely underestimated.

From the insurer's perspective, the costs of the surgery are balanced against the costs of morbidly obese insured persons. In one study [31], the medical expenses of morbidly obese members were 1.4 to 2.8 times that of other members. The difference for men $(\$ 16,000$ vs $\$ 6,000)$ was greater than for women $(\$ 11,000$ vs $\$ 8,000)$. From this finding, the authors deduced that the costs of surgery would be amortized in less than 3 years. Because the cost of obesity is likely to increase over time [32], a net economic benefit of surgery to the insurance company, if cost reduction is achievable, will occur at shorter and shorter intervals after the surgery.

\section{The economic impact of type 2 diabetes mellitus}

Bariatric surgery resolves type 2 diabetes mellitus for most of those afflicted with this problem [33]. Because of the impact on public health funding, expensive studies have been funded to evaluate pathogenesis and therapy [34, 35].

The American Diabetic Society estimate that in 2007, diabetes cost the U.S. economy $\$ 116$ billion in excess medical expenditures, $\$ 58$ billion in reduced national productivity, \$27 billion for direct care treatment of diabetes, $\$ 58$ billion to treat the portion of diabetes-related chronic complications attributed to diabetes, and $\$ 31$ billion in excess general medical costs [36]. Diabetic individuals incur an average of $\$ 11,744$ in medical expenses, $\$ 6,649$ of which is directed specifically at diabetes treatment. The largest components of medical expenditures attributed to diabetes are hospital inpatient care (50\% of the total cost), diabetes medication and supplies $(12 \%)$, retail prescriptions to treat complications of diabetes $(11 \%)$, and physician office visits $(9 \%)$.

Nondiabetic persons incur about 2.3 times less medical expense. Diabetes costs the U.S. labor workforce $\$ 60$ billion due to absenteeism, reduced labor productivity, unemployment due to disease-related disability unemployment, and early mortality. Part of the cost is attributable to diabetic comorbidities including insulin resistance, hypertension, coronary artery disease, cancer, arthritis, stroke, and diabetes mellitus [37, 38].

Although diabetes can sometimes be controlled through diet and exercise or by pharmaceutical intervention, bariatric surgery offers a permanent solution, precedent to significant weight loss [39, 40] for reasons that remain the subject of investigation [41-43]. Irrespective of the reason that bariatric surgery works, its economic value can be seen from the preceding analysis of one of obesity's comorbidities.

\section{Conclusions}

Obese patients are not in the same position as large financial institutions. They cannot expect trillions of bailout dollars simply because they are too large to fail. Instead, cost-benefit analyses are required if an overburdened health care system is to be persuaded to provide expensive surgery. Costs of obesity, as demonstrated in this report, can be divided into costs to the economy in general and to workers and insurance companies in particular. Costs can and should be assessed with respect to the varied complications of obesity, as shown by the analysis of diabetes. By such means as described, bariatric surgery's savings to the medical system might be demonstrated, most clearly 2-3 years postoperatively [11, 20, 44, 45].

\section{References}

1. Statistical Abstract of the United States (2007) U.S. Census Bureau, Washington, DC

2. Flegal KM, Carroll MD, Ogden CL, Johnson CL (2002) Prevalence and trends in obesity among U.S. adults, 1999-2000. JAMA 288:1723-1727

3. Calle EE, Rodriguez C, Walker-Thurmond K, Thun MJ (2003) Overweight, obesity, and mortality from cancer in a prospectively studied cohort of U.S. adults. N Engl J Med 348:1625-1638

4. Must A, Spadano J, Coakley EH, Fleid AE, Colditz G, Dietz WH (1999) The disease burden associated with overweight and obesity. JAMA 282:1523-1529 
5. Baum C, Ford W (2004) The wage effects of obesity: a longitudinal study. Health Econ 13:885-899

6. Swinburn B, Ashton T, Gillespie J et al (1997) Health care costs of obesity in New Zealand. Int J Obes 21:891-896

7. Thompson D, Edelsberg J, Colditz GA et al (1999) Lifetime health and economic consequences of obesity. Arch Intern Med 159:2177-2183

8. Thompson D, Wolf AM (2001) The medical care cost burden of obesity. Obes Rev 2:189-197

9. Wang G, Zheng ZJ, Heath G et al (2002) Economic burden of cardiovascular disease associated with excess body weight in U.S. adults. Am J Prev Med 23:1-6

10. Weintraub M (1992) Long-term weight control study conclusions. Clin Pharmocol Ther 51:642-646

11. Colditz GA (1999) Economic costs of obesity and inactivity. Med Sci Sports Exerc 31(Suppl 11):S663-S667

12. Wittgrove AC, Clark GW (2000) Laparoscopic gastric bypass, Roux-en-Y-500 patients: technique and results, with 3-60 month follow up. Obes Surg 10:233-239

13. Wolf AM (1998) What is the economic case for treating obesity? Obes Res 6(Suppl 1):2S-7S

14. Strum R (2003) Increases in clinically severe obesity in the United States, 1986-2000. Arch Surg 163:2146-2148

15. Sturm R (2002) The effects of obesity, smoking, and drinking on medical problems and cost outranks both smoking and drinking in its deleterious effects on health and health costs. Health Aff (Millwood) 21:245-253

16. Finkelstein EA, Fiebelkom IC, Wang G (2003) National medical spending attributable to overweight and obesity: how much and who's paying? Health Aff (Millwood) Jan-Jun(Suppl Web exclusives):W3-219-W3-226

17. Thompson D, Edelsberg J, Kinsey KL, Oster G (1998) Estimated economic costs of obesity on business. Am J Health Promot 13:120-127

18. Thorpe KE, Florence CS, Howard DH, Joski P (2004) The impact of obesity on rising medical spending. Health Aff (Millwood) July-Dec(Suppl Web exclusives):W4-480-W4486

19. Tucker LA, Friedman GM (1998) Obesity and absenteeism: an epidemiologic study of 10,825 employed adults. Am J Health Promot 12:202-207

20. Craig BM, Tseng DS (2002) Cost effectiveness of gastric bypass for severe obesity. Am J Med 113:491-498

21. Buchwald H, Avidor Y, Braunwald E, Jensen MD, Pories W, Fahrbach K, Schoelles K (2004) Bariatric surgery: a systematic review and meta-analysis. JAMA 292:1724-1737

22. Buchwald H (2005) Management of morbid obesity: surgical options. J Fam Pract S10-S17

23. Christou NV, Sampalis JS, Liberman M, Look D, Auger S, McLean AP et al (2004) Surgery decreases long-term mortality, morbidity, and health care use in morbidly obese patients. Ann Surg 240:416-423

24. Frezza EE, Wachtel M, Ewing BT (2006) The economic impact of morbid obesity on the state economy: an initial evaluation. Surg Obes Relat Dis 2:504-508

25. Perry CD, Hutter MM, Smith DB, Newhouse JP, McNeil BJ (2008) Survival and changes in comorbidities after bariatric surgery. Ann Surg 247(1):21-27

26. Fisher BL, Schauer P (2002) Medical and surgical options in the treatment of severe obesity. Am J Surg 184:S9
27. Flum DR, Salem L, Elrod JA, Dellinger EP, Cheadle A, Chan L (2005) Early mortality among Medicare beneficiaries undergoing bariatric surgical procedures. JAMA 294:1903-1908

28. Finkelstein MM (2001) Obesity, cigarette smoking, and the cost of physicians' services in Ontario. Can J Public Health 92:437-440

29. Sampalis JS, Liberman M, Auger S, Christou NV (2004) Impact of weight reduction health care costs in morbidly obese patients. Obes Surg 14:939-947

30. Finkelstein EA, Brown DS (2005) A cost-benefit simulation model of coverage for bariatric surgery among full-time employees. Am J Manag Care 11:641-646

31. Martin LF, Lundberg AP, Juneau F, Raum WJ, Hartman SJ (2005) A description of morbidly obese state employees requesting a bariatric operation. Surgery 138:690-700

32. Wolf AM, Colditz GA (1998) Current estimates of the economic cost of obesity in the United States. Obes Res 6:97-106

33. Buchwald H, Estok R, Fahrbach K, Banel D, Sledge I (2007) Trends in mortality in bariatric surgery: a systematic review and meta-analysis (review). Surgery 142:621-632 discussion 632-635

34. Detournay B, Cros S, Charbonnel B et al (2000) Managing type 2 diabetes in France: the ECODIA survey. Diabetes Metab 26: 363-369

35. Brolin RE (1996) Update: NIH consensus conference: gastrointestinal surgery for severe obesity. Nutrition 12:403-404

36. American Diabetes Association Statement (2008) Economic costs of diabetes in the U.S. in 2007. Diabetes Care 31:596-615

37. Hanusch-Enserer U, Edmund C, Brabant G, Dunky A, Rosen H, Pancini G, Tuchler H, Prager R, Roden M (2004) Plasma ghrelin in obesity before and after weight loss after laparoscopic adjustable gastric banding. J Clin Endocrinol Metab 89:3352-3358

38. Xu Y, Ohinata K, Meguid MM, Marx W, Tada T, Chen C, Quinn $\mathrm{R}$, Inui A (2002) Gastric bypass model in the obese rat to study metabolic mechanisms of weight loss. J Surg Res 107:56-63

39. Scopinaro N, Adami GF, Marinari GM et al (1998) Biliopancreatic diversion. World J Surg 22:936-946

40. Rubino F, Zizzari P, Tomasetto C et al (2005) The role of the small bowel in the regulation of circulating ghrelin levels and food intake in the obese Zucker rat. Endocrinology 146:1745-1751

41. Rubino F, Gagner M, Gentileschi P et al (2004) The early effect of the Roux-en-Y gastric bypass on hormones involved in body weight regulation and glucose metabolism. Ann Surg 240:236-242

42. Faraj M, Havel PJ, Phelis S, Blank D, Sniderman AD, Cianflone K (2003) Plasma acylation-stimulating protein, adiponectin, leptin, and ghrelin before and after weight loss induced by gastric bypass surgery in morbidly obese subjects. J Clin Endocrinol Metab 88:1594-1602

43. le Roux CW, Aylwin SJB, Batterham RL, Borg CM, Coyle F, Prasad V, Shurey S, Ghatei MA, Patel AG, Bloom SR (2006) Gut hormone profiles following bariatric surgery favor an anorectic state, facilitate weight loss, and improve metabolic parameters. Ann Surg 243:108-114

44. Van Gemert WG, Adang EM, Kop M, Vos G, Greve JW, Soeters PB (1999) A prospective effectiveness analysis of vertical banded gastroplasty for the treatment of morbid obesity. Obes Surg 9:484-491

45. Clegg A, Colquitt J, Sidhu M, Royle P, Walker A (2003) Clinical and cost effectiveness of morbid obesity: a systematic review and economical evaluation. Int $\mathrm{J}$ Obes Relat Metab Disord 27: $1167-1177$ 